\title{
O PENSAMENTO AGRÁRIO ACERCA DA PROBLEMÁTICA SOCIOAMBIENTAL
}

\section{Victor Pereira de Sousa ${ }^{1}$}

Resumo: O pensamento agrário se entrelaça a Geografia Agrária em vias da renovação de suas ações e práticas que foram se alterando conforme a evolução do ser humano sob a superfície terrestre, analisando desde o surgimento da agricultura, passando pela corrente desenvolvimentista que ocasionou na Revolução Verde, até chegar à corrente de desenvolvimento sustentável que proporcionou o surgimento da Agroecologia. Dessa forma, baseado em estudos metodologicamente bibliográficos, fundamentado em grandes obras literárias e autores de grande expoente no tema, o presente trabalho apresenta a agricultura se renovando em meios de propor novos conhecimentos e técnicas que possam atender às necessidades de compreensão dos novos desenhos que a humanidade elabora ao se desenvolver no espaço geográfico, em busca de um desenvolvimento que possa ser dito como sustentável.

Palavras-chave: Agricultura; Revolução Verde; Agroecologia; Geografia Agrária.

1 Graduando em Geografia, Universidade do Estado do Rio de Janeiro (UERJ), Brasil. E-mail: victordesousa@outlook.com.br. 